\title{
Different expression of lumican glycoforms in non-metastatic and metastatic laryngeal squamous cell carcinoma
}

\section{Različit izražaj glikoformi lumikana u nemetastatskom i metastatskom karcinomu pločastih stanica grkljana}

\author{
Iris Car $^{1}$, Sarah Visentin ${ }^{1}$, Davorin Đanić2 ${ }^{2}$ Marko Klobučar ${ }^{1 *}$
}

${ }^{1}$ University of Rijeka, Department of Biotechnology, Centre for High-throughput technologies, Rijeka, Croatia

${ }^{2}$ University Josip Juraj Strossmayer of Osijek, Faculty of dental medicine and health, Osijek, Croatia
Abstract. Objective: Association of altered growth factor receptors-mediated intracellular pathways and biological processes associated with extracellular matrix composition and structure in laryngeal squamous cell carcinoma (LSCC) were described previously. In particular, the expression and glycosylation of important extracellular matrix molecules (ECM) such as small leucine rich proteoglycan lumican, may be generally associated with disrupted extracellular matrix integrity and inflammation processes which have a role in tumour invasiveness. In this study, the relative expression of different lumican glycoforms were evaluated in primary tumour and tumour-unaffected tissue samples of ten patients with metastatic and ten non-metastatic LSCC by Western blot and 2D immunoblot analysis. Materials and methods: Tissue samples from the primary tumours and paired adjacent nontumour tissues were surgically resected from ten untreated LSCC patients with nonmetastatic disease and ten LSCC patients with lymph nodes metastases. The relative expression of different lumican glycoforms in primary tumours and paired adjacent nontumour tissues were evaluated by Western blot and 2D immunoblot analysis. Results: Results of Western blot analysis have revealed elevated expression of the moderately glycosylated lumican form in metastatic $(p<0,05)$ and non-metastatic primary tumour tissues in comparison with tumour unaffected tissues. In addition, moderately glycosylated form of lumican with negatively charged oligosaccharide residues in the $\mathrm{N}$-glycan molecule part was exclusively determined in metastatic primary tumour tissues by $2 \mathrm{D}$ immunoblot analysis. Conclusion: We demonstrated elevated expression of the moderately glycosylated lumican form with negatively charged oligosaccharide residues in the $\mathrm{N}$-glycan portion exclusively in primary laryngeal squamous cell carcinoma from patients with metastatic disease.

Key words: biological function; glycosylation; laryngeal squamous cell carcinoma; lumican; metastases; overexpression

Sažetak. Cilj: Prijašnje su studije opisale povezanost između promijenjenih staničnih signalnih puteva posredovanih receptorima za faktore rasta i narušenog integriteta izvanstaničnog matriksa u karcinomu pločastih stanica grkljana. Izražaj i glikozilacija molekula izvanstaničnog matriksa, poput proteoglikana lumikana, može biti povezana $s$ narušenim integritetom izvanstaničnog matriksa i upalnim procesima koji imaju važnu ulogu prilikom invazije tumora. U ovom smo radu pomoću Western blot i 2D imunoblot metoda ispitali relativni izražaj različitih glikoformi lumikana u uzorcima primarnog tumora i tumorom nezahvaćenog tkiva 10 pacijenata oboljelih od metastatskog i 10 od nemetastatskog karcinoma pločastih stanica grkljana. Materijali i metode: Uzorci tkiva primarnih tumora i pripadajućih tumorom nezahvaćenih histološki neizmijenjenih tkiva prikupljeni su tijekom kirurške resekcije 10 pacijenata oboljelih od metastatskog karcinoma i 10 od nemetastatskog karcinoma. Razina relativnog izražaja glikoformi lumikana u tkivima primarnih tumora i pripadajućim tumorom nezahvaćenim tkivima ispitana je uz pomoć Western blot i 2D imunoblot metoda. Rezultati: Rezultati Western blot analize pokazali su povećan izražaj umjereno glikozilirane forme

http://hrcak.srce.hr/medicina 
lumikana u tkivima primarnih tumora pacijenata oboljelih od metastatske $(p<0,05)$ i nemetastatske bolesti u usporedbi s pripadajućim tumorom nezahvaćenim tkivima. Uz ovo, umjereno glikozilirana forma lumikana s negativno nabijenim ugljikohidratnim ostacima u $\mathrm{N}$-glikanskom dijelu molekule isključivo je detektirana u tkivima metastatskog primarnih tumora pomoću 2D imunoblot analize. Zaključci: Dokazali smo povećan izražaj umjereno glikozilirane forme lumikana $s$ negativno nabijenim oligosaharidnim ostacima u $\mathrm{N}$-glikanskom dijelu isključivo u primarnom karcinomu pločastih stanica grkljana kod pacijenata s metastatskom bolesti.

Ključne riječi: biološka funkcija; glikozilacija; karcinom pločastih stanica grkljana; lumikan; metastaze; povećan izražaj

\section{INTRODUCTION}

Laryngeal squamous cell carcinoma (LSCC) is a multifactorial disease characterized by frequent metastasis in lymph nodes early during disease onset, and represents the most common form of head and neck malignancies ${ }^{1}$. Recent evidence indicates a clear association between altered growth factor receptors-mediated intracellular pathways and biological processes underlying LSCC that induce changes in the extracellular matrix $(E C M)^{2,3}$. Lumican is an important ECM protein that belongs to a class II small leucine rich proteoglycans and has four potential N-glycosylation sites $^{4}$. Depending on the tissue type, it is expressed in different structural forms, including the core protein with MW approximately $40 \mathrm{kDa}$, the $70 \mathrm{kDa}$ proteoglycan substituted with keratane-sulphate or nonsulphated polylactosamine chain and the $50 \mathrm{kDa}$ glycoprotein form ${ }^{5}$. Also, depending on its glycosylation status, lumican bears different biological functions or contributes to progression of malignancies by stimulating cellular signalization, proliferation and migration ${ }^{6,7}$.

In this study, we hypothesized that expression of different glycoforms of lumican might be important for the LSCC pathogenesis. Herein, we present data on lumican glycoforms expression in a set of 10 metastatic and 10 non-metastatic primary LSCC tumours.

\section{MATERIALS AND METHODS}

\section{Tissue Samples}

Tumour tissue samples from the centre of the tumour and paired adjacent non-tumour mucosa tissues located $>1 \mathrm{~cm}$ distance from the site of the primary tumour were surgically resected from ten previously untreated LSCC patients with non-metastatic disease and ten LSCC patients with lymph nodes metastases. The main clinical and pathological characteristics of patients are shown in Table 1. All experiments were conducted with the approval of the Ethics committee of General Hospital "Dr. Josip Benčević", Slavonski Brod, Croatia, and the informed consent was signed by the patients enrolled in this study.

We have for the first time to our knowledge demonstrated the expression of the lumican glycoform with negatively charged oligosaccharide residues in $\mathrm{N}$-glycan portion of the molecule exclusively in tumour tissues from metastatic disease patients.

\section{Preparation of Tissue Homogenates for Western Blot and 2D Immunoblot Analysis}

Tumour and adjacent tumour-unaffected tissue samples were mechanically grinded and homogenized in a mortar with liquid nitrogen. Homogenized tissue was dissolved in a lysis buffer [7M urea/2M thiourea, 4\% (w/v) CHAPS, 1\% (w/v) dithiothreitol,1x protease inhibitor cocktail; SigmaAldrich, USA] and subjected to sonication with $4 \mathrm{~mm}$ probe, power of $6 \mathrm{~W}$, four times for $10 \mathrm{sec}-$ onds (Bandelin, Germany). After sonication, samples were incubated for 1 hour at room temperature. Samples were then centrifuged for 45 minutes at $14000 \mathrm{rpm}$, at $4^{\circ} \mathrm{C}$. The supernatant was collected and stored at $-80^{\circ} \mathrm{C}$. Protein concentrations were determined using the Qubit ${ }^{\mathrm{TM}}$ fluorometric (Invitrogen, USA) quantitation platform.

\section{Western Blot Analysis}

For the Western blot procedure, a total of $50 \mu \mathrm{g}$ proteins from tumour and tumour-unaffected surrounding tissues were resolved on $10 \%$ SDSPAGE and transferred to PVDF membrane (BioRad, USA). Membranes were then incubated with primary antibody raised against human lumican (1:1000, rabbit $\mathrm{mAb}, \mathrm{Abcam}, \mathrm{UK})$ at $4^{\circ} \mathrm{C}$ overnight respectively. Signal intensities of particular bands were normalized according to total protein stain $^{8}$, an alternative simple technique for accu- 
Table 1. Main clinical and pathological characteristics of patients.

\begin{tabular}{|c|c|c|}
\hline \multicolumn{3}{|c|}{ Clinical /Pathological parameters } \\
\hline & Non metastatic tumour samples (No.) & Metastatic tumour samples (No.) \\
\hline \multicolumn{3}{|l|}{ Gender } \\
\hline Male & 9 & 10 \\
\hline Female & 1 & 0 \\
\hline \multicolumn{3}{|l|}{ Age (years) } \\
\hline$<64$ (median) & 6 & 4 \\
\hline » 64 & 4 & 6 \\
\hline \multicolumn{3}{|l|}{ T-stage } \\
\hline T1 & 1 & 0 \\
\hline T2 & 2 & 5 \\
\hline T3 & 4 & 4 \\
\hline $\mathrm{T} 4 \mathrm{a}$ & 3 & 1 \\
\hline \multicolumn{3}{|l|}{$\mathbf{N}$-stage } \\
\hline NO & 10 & 0 \\
\hline N1 & 0 & 2 \\
\hline $\mathrm{N} 2 \mathrm{~b}$ & 0 & 7 \\
\hline N2c & 0 & 1 \\
\hline \multicolumn{3}{|c|}{ Histological grade } \\
\hline GI & 2 & 2 \\
\hline GII & 6 & 1 \\
\hline GIII & 2 & 7 \\
\hline
\end{tabular}

Our findings implicate that LSCC progression could be linked to changes in lumican relative expression and glycosylation status. These alterations could be associated with disrupted ECM integrity and enhanced inflammation, which are commonly encountered in progression of malignant diseases.

rate determination of equivalent protein loading within a gel and were compared in Quantity One software (Bio-Rad, USA).

\section{D Immunoblot Analysis}

For 2D immunoblot analysis of different lumican glycoforms, a total of $75 \mu \mathrm{g}$ of proteins from all individual primary tumour and adjacent tumour unaffected surrounding tissues that had a positive lumican immunoreactivity were redissolved in sample rehydration buffer [7M urea/2M thiourea, $4 \%(w / v)$ CHAPS, $0.2 \%(w / v)$ mixture of ampholytes $\mathrm{pH} 3-10,1 \%(\mathrm{w} / \mathrm{v})$ dithiothreitol; SigmaAldrich, USA] and subjected to 2DE electrophoresis as described previously ${ }^{9}$. Isoelectric focusing was carried out on a Protean IEF Cell (Bio Rad) by using broad range IPG strips $(7 \mathrm{~cm}$ IPG strips, $\mathrm{pH}$ 3.0-10.0). The IEF-separated proteins were resolved on $10 \%$ SDS-PAGE and transferred to PVDF membrane. Membranes were then incubated with primary lumican antibody at $4^{\circ} \mathrm{C}$ overnight. The signal was visualized on the ImageQuant LAS500 (GE Healthcare, USA).

\section{PNGase F Removal of N-Glycans}

A total of $75 \mu \mathrm{g}$ of extracted proteins from tumour- and tumour-unaffected tissue lysates that have shown positive lumican immunoreactivity were de-glycosylated by the treatment with Peptide:N-glycosidase F (Promega, USA) at the ratio of 50 units PNGase $F$ per $\mathrm{mg}$ protein at $37^{\circ} \mathrm{C}$ for 18 hours.

\section{Statistical analysis}

Normalised densitometric data obtained from Western blot analysis of lumican relative expression were tested for normality by using ShapiroWilk test. As data were not normally distributed, a Wilcoxon-signed rank test $(p<0,05)$ was used to test differences in lumican relative expression between primary tumours and adjacent tumourunaffected tissues, separately for the metastatic and the non-metastatic group of patients. All sta- 
tistical analyses were performed in Statistica software package (v.12.0).

\section{RESULTS}

Western blot analysis of lumican relative expression revealed significant up-regulation $(p=0.009)$ of this proteoglycan in primary tumour tissues with lymph node metastases in comparison with matched adjacent non-tumour tissues (Figure 1A). Molecular weight of detected chemiluminescent signals of lumican in all analysed tissue samples (including metastatic primary tumours and matched adjacent non-tumour tissues) was approximately $50 \mathrm{kDa}$ (Figure $1 \mathrm{~A}$ ). This is in line with previous observations indicating that this particular lumican form corresponds to the soluble, moderately glycosylated form ${ }^{10}$. Also, an interesting observation is substantial loss of lumican expression in adjacent non-tumour tissues from metastatic disease patients. This unexpected finding could be attributed to loss of the tumour underlying tissue integrity associated with enhanced local invasion in LSCC.

Similarly, increased lumican expression, albeit without statistical significance $(p=0.139)$, was observed in primary tumours with non-metastatic disease in comparison with matched adjacent non-tumour tissues (Figure 1B). Again, in all ana-

A

B

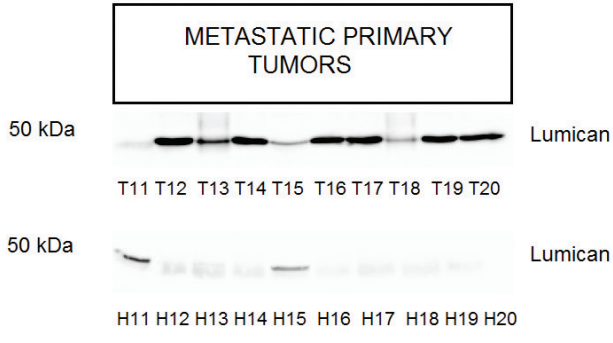

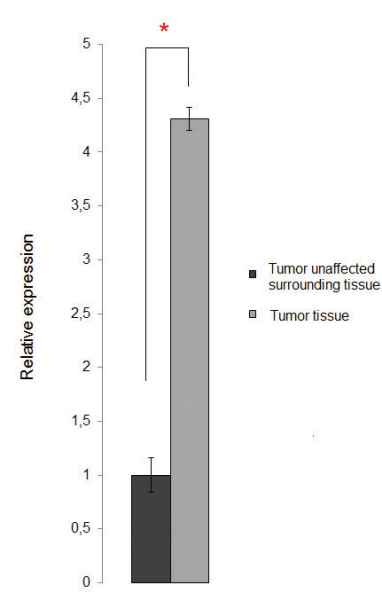

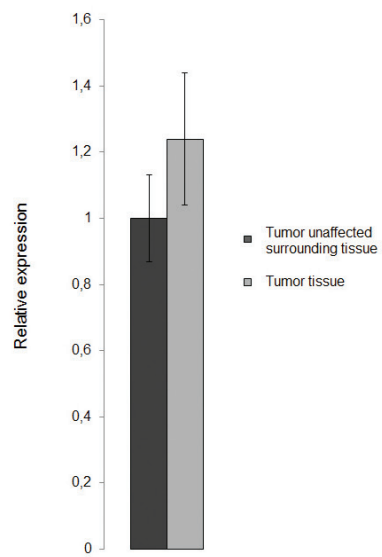

Figure 1. Representative Western blot and summary representation of lumican relative expression in samples obtained from 10 different patients that suffer from metastatic (A) and non-metastatic (B) LSCC, respectively. Results are presented as average relative expression values + standard error of chemiluminescent signals obtained in three replicate experiments. Statistically significant change (Wilcoxon- signed rank test, $p=0.009$ ) of lumican relative expression observed in the metastatic group of patients is marked with an asterisk. Abbreviations: T 1-10 - primary tumour tissue samples from 10 different patients with non-metastatic disease; H 1-10 - matched tumour unaffected tissue samples from same patients. T11-20 - primary tumour tissue samples from 10 different patients with metastatic disease; H 11-20 - matched tumour unaffected tissue samples from same patients. 

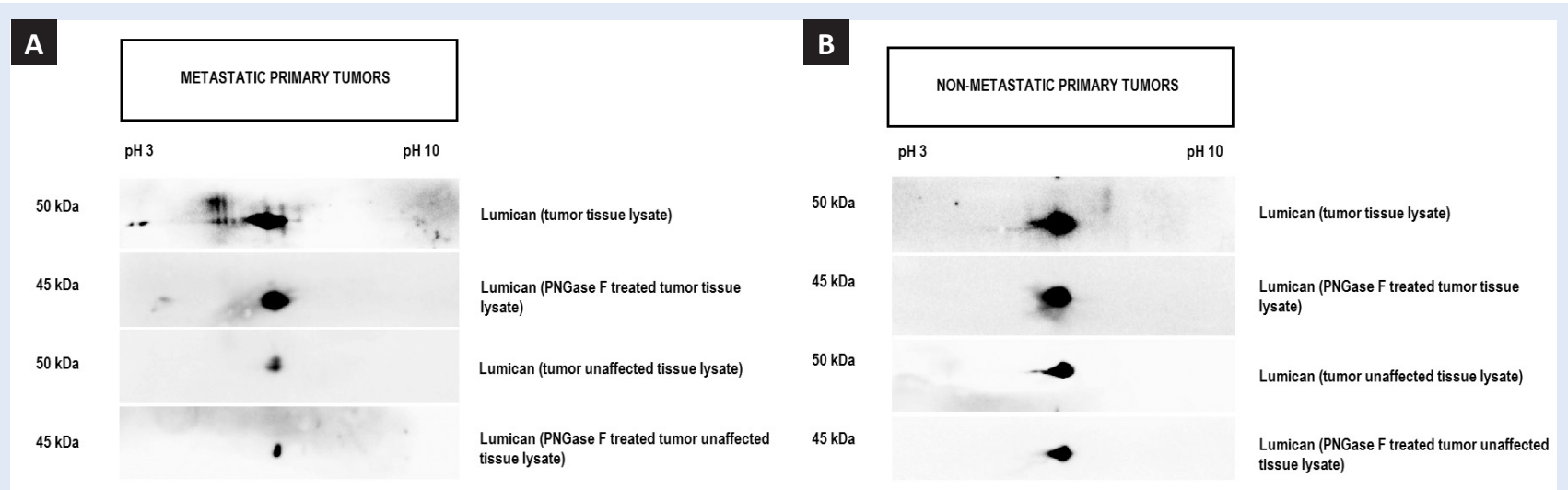

Figure 2. (A) Representative 2D immunoblots with lumican glycoforms signals in PNGase F untreated and treated tissue lysates of the metastatic primary tumour and tumour unaffected tissues; (B) Representative 2D immunoblots with lumican glycoforms signals in PNGase F untreated and treated tissue lysates of the non-metastatic primary tumour and tumour unaffected tissues.

lysed non-metastatic primary tumours and matched adjacent non-tumour tissue samples, observed signals for lumican were approximately of $50 \mathrm{kDa}$ (Figure 1B).

It is known that different post-translation modifications, i.e. negatively charged carbohydrate residues in glycan portion of glycoproteins, may generally contribute to the shift in the protein isoelectric point $(\mathrm{pl})^{11,12}$. In order to investigate possible association between altered lumican glycosylation and LSCC progression, all tissue lysates that showed positive lumican immunoreactivity were further subjected to 2DE immunoblot analysis prior and upon enzymatic removal of $\mathrm{N}$-linked glycans. In all analysed individual primary tumour lysates from the metastatic group, expression of lumican glycoforms was visible in a wide range of pls between $\mathrm{pH}$ 3-6 (Figure 2A). This might be due to $\mathrm{N}$-linked glycosylation and may not correlate to other post-translational modifications of lumican ${ }^{13}$. Therefore, tissue lysates were additionally subjected to PNGase F enzymatic removal of $\mathrm{N}$-linked glycans. In addition to a slight decrease in MW, a shift of the lumican signal to an approximate $\mathrm{pH}$ value of 6.0 was detected (Figure 2A), which may be indicative of the presence of negatively charged oligosaccharide residues in the $\mathrm{N}$-glycan portion of the molecule. This observation is in line with previous studies that provided evidence to confirm the contribution of negatively charged oligosaccharide residues in $\mathrm{N}$-glycan chains with de- creased protein $\mathrm{pl}$ values ${ }^{10,12}$. Furthermore, in matched adjacent non-tumour tissues from the metastatic group, that showed positive lumican immunoreactivity, lumican signal was observed around the $\mathrm{pH} 6.0$ (Figure $2 \mathrm{~A}$ ).

Similarly, expression of lumican glycoforms signal was observed at approximate $\mathrm{pH}$ value of 6.0 in non-metastatic tumour and paired non-tumour tissue lysates (Figure 2B). In addition, enzymatic removal of $\mathrm{N}$-glycans decreased lumican $\mathrm{MW}$, but without a shift in the protein pl value (Figure $2 \mathrm{~B}$ ).

\section{DISCUSSION}

Impaired structural and functional dynamics of the ECM is an important factor that contributes to a number of malignancies, including $\mathrm{HNSCC}^{14}$. Such major structural changes in the composition and structure of the ECM often result in the activation of growth factor-mediated cellular signalling pathways that play a role in malignant transformation and invasion of tumour cells or in the host stromal cells homeostasis. These molecular events eventually contribute to formation of a tumour-supportive microenvironment and promote processes associated with local invasion and metastasis ${ }^{15}$. Lumican is the ECM protein that has an important role in maintaining structural tissue homeostasis. Altered lumican expression was previously associated with disrupted extracellular matrix integrity and enhanced inflammation, which facilitates the progression of various diseases including tumours ${ }^{16}$. Important- 
ly, biological role of lumican is closely associated with its glycosylation status ${ }^{17,18}$. Indeed, our results clearly showed that moderately glycosylated form of lumican is upregulated in the all analysed primary tumours in comparison with matched adjacent non-tumour tissues. Also, it should be noted that tumour surrounding tissue used in this study may also be affected by altered physiological processes associated with the tumour promoting microenvironment. The tumour microenvironment is a web of various cell types and extracellular matrix components in the vicinity of the tumor ${ }^{18,19}$. It is well known that deregulated molecular crosstalk between tumour cells and components of the tumour microenvironment plays a pivotal role in tumour progression ${ }^{20}$.
In addition, these molecular interactions are largely mediated by the inflammatory response, which represents a fundamental component of the tumour microenvironment ${ }^{21,22}$. Considering this, it is reasonable to assume that detected lumican glycoforms in adjacent non- tumour tissues may also be involved in LSCC pathogenesis. This hypothesis is supported with the results of previous studies which have demonstrated that soluble, poorly glycosylated lumican form acts as an endogenous ligand for various immune cells receptors, including CD14 on neutrophils and macrophages ${ }^{23,24}$. It's binding to the receptor results in recruitment of immune cells on the site of inflammation, activation of NfkB intracellular signalling and production of pro-inflammatory
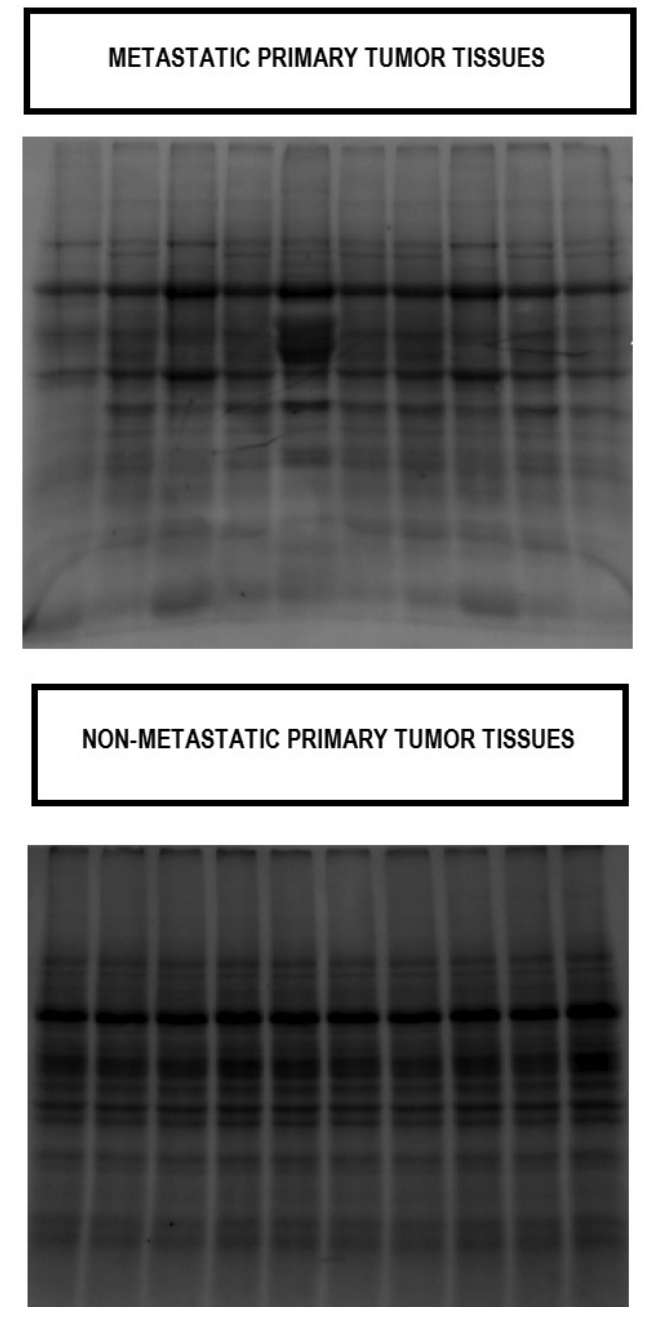
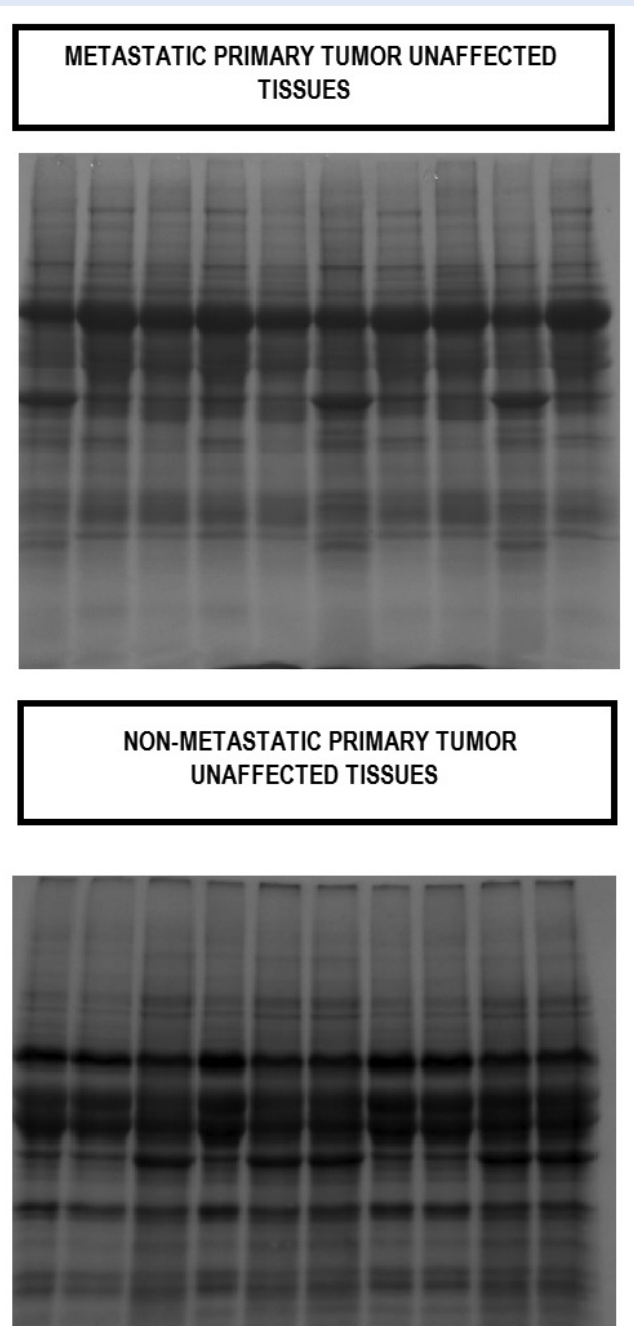

Supplementary figure: Representative total protein stain of PVDF membranes transferred proteins isolated from the metastatic primary tumours, metastatic primary tumour unaffected tissues, non-metastatic primary tumours, and non-metastatic primary tumour unaffected tissues. 
cytokines. Moreover, our previous study showed elevated expression of CD14 receptors and components of $\mathrm{NfkB}$ cellular signaling pathway in both primary LSCC and adjacent non-tumour tissues $^{25}$, which further suggests the possible involvement of lumican in LSCC associated inflammation.

Furthermore, 2D immunoblot analysis revealed presence of the $50 \mathrm{kDa}$ lumican glycoform with negatively charged oligosaccharide residues in $\mathrm{N}$ glycan portion of the molecule exclusively in tumour tissues from metastatic disease patients. This finding implicates that LSCC progression could be associated with changes in lumican relative expression concomitant with alternation in its glycosylation status, which was previously reported in various cancer cell lines ${ }^{19,20}$. Interestingly, similar lumican 50 kDa glycoprotein form with negatively charged oligosaccharide residues in $\mathrm{N}$ glycan portion was previously isolated from human amniotic membrane. Its effect was tested on corneal epithelial cells that showed to have an enhanced proliferation rate upon treatment with the $50 \mathrm{kDa}$ glycoprotein lumican form in an organ culture, which was speculated to be a consequence of binding and presenting growth factors and cytokines to various membrane receptors ${ }^{10}$. It was shown that overexpression of growth factor receptors and their ligands is associated with LSCC progression and metastasis ${ }^{21,22}$.Thus, it is reasonable to assume that soluble lumican might also contribute to LSCC progression in a similar manner. However, this hypothesis requires further investigation.

Also, the findings of this study have to be seen in light of some limitations. To gain a more comprehensive understanding of lumican expression changes in LSCC, further research should include immunohistochemical analyses of lumican relative expression and its exact spatial distribution in a larger number of LSCC tissue samples. Also, to further clarify the role of lumican in complex molecular signalling networks associated with LSCC progression, additional immunoprecipitation experiments of protein complexes containing lumican followed by their mass spectrometry identification are also recommended. In addition, a detailed mass spectrometric structural charac- terization of lumican N-glycans would further elucidate the biological role of its differential glycosylation in LSCC pathogenesis.

\section{CONCLUSIONS}

In conclusion, we demonstrated elevated expression of the moderately glycosylated lumican form with negatively charged oligosaccharide residues in the $\mathrm{N}$-glycan portion exclusively in primary laryngeal squamous cell carcinoma from metastatic patients.

\section{Funding}

This research was funded through the University of Rijeka research grant 13.11.1.1.11.

\section{Acknowledgements}

We greatly acknowledge the support of University of Rijeka research grant 13.11.1.1.11 and the project "Research Infrastructure for Campus-based Laboratories at University of Rijeka", co-financed by European Regional Development Fund (ERDF). Also we greatly acknowledge to Professor Davorin Đanić (Department of ENT and Head and Neck Surgery, General Hospital "Dr. J. Benčević") for supervision of all clinical procedures and collection of LSCC tissue samples included in this study.

Conflict of interest: Authors have no conflict of interest to declare.

\section{REFERENCES}

1. Mirisola V, Mora R, Esposito Al, Guastini L, Tabacchiera F, Paleari $L$ et al. A prognostic multigene classifier for squamous cell carcinomas of the larynx. Cancer Lett 2011; 307:37-46.

2. Bonnans C, Chou J, Werb Z. Remodelling the extracellular matrix in development and disease. Nat Rev Mol Cell Biol 2014;15:786-801.

3. Grzelczyk WL, Wróbel-Roztropiński A, Szemraj J, Cybula M, Pietruszewska W, Zielińska-Kaźmierska B et al. Matrix metalloproteinases (MMPs) and inhibitor of metalloproteinases (TIMP) mRNA and protein expression in laryngeal squamous cell carcinoma. Arch Med Sci 2019;15:784-91.

4. Appunni S, Anand V, Khandelwal M, Gupta N, Rubens M, Sharma A. Small Leucine Rich Proteoglycans (decorin, biglycan and lumican) in cancer. Clin Chim Acta Int J Clin Chem 2019;491:1-7.

5. Nikitovic D, Katonis P, Tsatsakis A, Karamanos NK, Tzanakakis GN. Lumican, a small leucine-rich proteoglycan. IUBMB Life 2008;60:818-23.

6. Brézillon S, Pietraszek K, Maquart F-X, Wegrowski Y. Lumican effects in the control of tumour progression and their links with metalloproteinases and integrins. FEBS J 2013;280:2369-81. 
7. Pratt M, Kang Y, Li X, Fleming JB. Lumican, a Small Leucine-Rich Proteoglycan, and Its Biological Function in Tumor Progression. In: Brekken RA, Stupack D (eds). Extracellular Matrix in Tumor Biology. Cham: Springer International Publishing, 2017;39-49.

8. Eaton SL, Roche SL, Llavero Hurtado M, Oldknow KJ, Farquharson C, Gillingwater TH et al. Total protein analysis as a reliable loading control for quantitative fluorescent Western blotting. PloS One 2013;8:e72457.

9. Kleinert P, Kuster T, Arnold D, Jaeken J, Heizmann CW, Troxler $\mathrm{H}$. Effect of glycosylation on the protein pattern in 2-D-gel electrophoresis. Proteomics 2007;7:15-22.

10. Yeh L-K, Chen W-L, Li W, Espana EM, Ouyang J, Kawakita T et al. Soluble Lumican Glycoprotein Purified from Human Amniotic Membrane Promotes Corneal Epithelial Wound Healing. Invest Ophthalmol Vis Sci 2005;46:479-86.

11. Magdeldin S, Enany S, Yoshida Y, Xu B, Zhang Y, Zureena $Z$ et al. Basics and recent advances of two dimensionalpolyacrylamide gel electrophoresis. Clin Proteomics 2014;11:16.

12. Barrabés S, Sarrats A, Fort E, De Llorens R, Rudd PM, Peracaula $\mathrm{R}$. Effect of sialic acid content on glycoprotein pl analyzed by two-dimensional electrophoresis. Electrophoresis 2010;31:2903-12.

13. Dunlevy JR, Rada JAS. Interaction of lumican with aggrecan in the aging human sclera. Invest Ophthalmol Vis Sci 2004;45:3849-56.

14. Lu P, Weaver VM, Werb Z. The extracellular matrix: a dynamic niche in cancer progression. J Cell Biol 2012;196: 395-406.
15. Markwell SM, Weed SA. Tumor and stromal-based contributions to head and neck squamous cell carcinoma invasion. Cancers 2015;7:382-406.

16. Iozzo RV, Schaefer L. Proteoglycans in health and disease: novel regulatory signaling mechanisms evoked by the small leucine-rich proteoglycans. FEBS J 2010;277: 3864-75.

17. Nikitovic D, Papoutsidakis A, Karamanos NK, Tzanakakis GN. Lumican affects tumor cell functions, tumor-ECM interactions, angiogenesis and inflammatory response. Matrix Biol 2014;35:206-14.

18. Frey H, Schroeder N, Manon-Jensen T, Iozzo RV, Schaefer L. Biological interplay between proteoglycans and their innate immune receptors in inflammation. FEBS J 2013; 280:2165-79.

19. Ping Lu $\mathrm{Y}$, Ishiwata $\mathrm{T}, \mathrm{Asano} \mathrm{G}$. Lumican expression in alpha cells of islets in pancreas and pancreatic cancer cells. J Pathol 2002;196:324-30.

20. Seya T, Tanaka N, Shinji S, Yokoi K, Koizumi M, Teranishi $\mathrm{N}$ et al. Lumican expression in advanced colorectal cancer with nodal metastasis correlates with poor prognosis. Oncol Rep 2006;16:1225-30.

21. Bossi P, Resteghini C, Paielli N, Licitra L, Pilotti S, Perrone F. Prognostic and predictive value of EGFR in head and neck squamous cell carcinoma. Oncotarget 2016;7: 74362-79.

22. Szturz P, Raymond E, Abitbol C, Albert S, de Gramont A, Faivre S. Understanding c-MET signalling in squamous cell carcinoma of the head \& neck. Crit Rev Oncol Hematol 2017;111:39-51. 